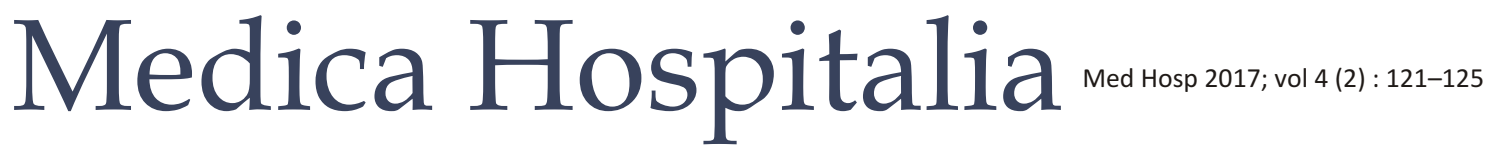

Original Article

\section{Dampak Smartphone dengan Kejadian Myopia Pada Anak di TK Melati Sambiroto Semarang}

\author{
Sri Suparti
}

Program Studi Refraksi Optisi STIKES Widya Husada Semarang

Kata Kunci : Anak, Smartphone, Myopia

\begin{abstract}
Abstrak
Latar belakang : Dengan adanya teknologi baru permainan tradisional berganti dengan bermain, belajar menggunakan smartphone. Kebiasaan bermain atau belajar menggunakan smartphone akan mengalami kelainan refraksi. Kelainan refraksi merupakan salah satu penyebab kebutaan dan hambatan penglihatan saat beraktivitas. Kelainan refraksi antara lain: Hipermetropia, Astigmatisma, Myopia.

Metode : Penelitian ini penelitian observasional analitik dengan menggunakan disain cross sectional. Sampel pada penelitian ini anak TK Melati Sambiroto Semarang sebanyak 42. Pengambilan data dilakukan dengan pemeriksaan obyektif. Data yang diperoleh dianalisis dengan menggunakan uji Chi Square.

Hasil : Lama penggunaan smartphone menunjukan prosentase $(81,8 \%)$ lebih dari 2 jam/hari dengan $(p=0,000)$. Genetik menunjukan prosentase $(81.3 \%)$ mengalami myopia dengan $(p=0,004)$. Posisi penggunaan Smartphone menunjukan prosentase $(68,0 \%)$ tidak duduk tegak dengan $(p=0,012)$

Simpulan : Dari hasil penelitian ini menunjukan ada hubungan bermakna antara lama menggunakan smartphone dan faktor genetik dengan kejadian myopia. Posisi penggunaan smartphone menunjukkan ada hubungan dengan kejadian myopia.
\end{abstract}

\section{Smartphone impact on children with events myopia in TK Melati Sambiroto Semarang}

\begin{abstract}
Background : With the new technology changing the traditional game study with Smartphone. The habitual play or study with to smartphone will have refraction disorder. Refractive disorders is one of that make blindness and disturb activity. Refractive disorder include Hypermetropia, Astigmatism, Myopia.

Methods : This study was analytic observational research with cross sectional design. The sampel research TK Melati Sambiroto Semarang 42 respondents. Data is collected by an objective examination.The data obtained were analyzed using Chi Square test.

Results : Smartphone usage long shows the percentage (81.8\%) more than 2 hours /day with $(p=0.000)$. Genetic shows the percentage $(81.3 \%)$ make myopia with $(p=0.004)$. Smartphone usage position shows the percentage $(68.0 \%)$ do not sit up $(p=0.012)$

Conclusion : From the research of this study shows that significant correlation between the long smartphones and genetic factors to the incidence of myopia. Smartphone usage position showed correlation with the incidence of myopia.
\end{abstract}

Keywords : Children, Smartphone, Myopia

\section{PENDAHULUAN}

Masa anak-anak adalah masa keemasan dimana anakanak berada dalam masa bermain serta belajar terhadap apa yang belum diketahuinya, smartphone telah menyediakan beragam aplikasi yang sangat bervariasi. Permainan anak-anak yang dulu hanya dapat dilakukan secara tradisional dan sederhana, seperti menata puzzle di atas papan sederhana, kini dapat dilakukan pada perangkat mobile komunikasi, banyak anak-anak yang lebih menyukai bermain dengan teknologi baru seperti playstation, game online, handphone, tablet ataupun ipad, teknologi ini memiliki sisi positif dan negatif terhadap perkembangan untuk anak yang menggunakanya. (Juniver V Mokalu 2016).

Menurut Gary B Thomas dan Misty E, (2007) smartphone adalah telepon yang internet enabled yang biasanya menyediakan fungsi personal digital assistant (PDA), seperti fungsi kalender, buku agenda, buku alamat, kalkulator dan alamat. Rini (2011) Dampak 
negatif atau pengaruh buruk bagi anak, yaitu terhadap kesehatan, kepribadian, pendidikan/prestasi, serta terhadap keluarga dan masyarakat. Seorang anak yang memiliki kebiasaan bermain dengan teknologi baru seperti playstation, game online, handphone, tablet ataupun ipad mengalami kelainan refraksi.

Kelainan refraksi merupakan salah satu penyebab kebutaan dan hambatan penglihatan saat beraktivitas. Kelainan refraksi antara lain: Ametropia yaitu keadaan pembiasan mata dengan panjang bola mata yang tidak seimbang. Adapun ametropia dapat ditemukan dalam bentuk-bentuk kelainan, anatara lain : (1) Hipermetropia atau rabun dekat merupakan keadaan gangguan kekuatan pembiasan mata dimana sinar sejajar jauh tidak cukup dibiaskan sehingga titik fokusnya terletak dibelakang retina; (2) Astigmatisma adalah dimana berkas sinar tidak difokuskan pada satu titik dengan tajam pada retina akan tetapi pada dua garis titik api yang saling tegak lurus yang terjadi akibat kelainan kelengkungan permukaan kornea; (3) Miopia atau rabun jauh yaitu keadaan dimana panjang bola mata anteroposterior dapat telalu besar atau kekuatan pembiasaan media refraksi terlalu kuat. (S. Ilyas 2008).

Sebagaimana penelitian sebelumnya menurut Kinge (2000) terdapat hubungan yang bermakna antara progresivitas miopia dengan waktu yang dihabiskan selama membaca maupun aktivitas jarak dekat lainnya $(p<0,06)$. Hal ini dipengaruhi oleh jenis kerja jarak dekat yang dilakukan, yaitu pada saat membaca terdapat komponen saccadiac mata yang mempengaruhi kerja otot mata, sehingga kelelahan mata lebih cepat timbul dan timbulnya myopia lebih besar (Nurkasih 2010 (Djua 2015)).

Pada mata miopia, bola mata terfiksasi pada posisi memanjang menyulitkan untuk melihat objek jauh. Faktor lingkungan yang paling berperan pada penderita miopia adalah adanya aktivitas pekerjaan yang terus menerus seperti membaca buku dalam keadaan dekat serta posisi berbaring, menonton televisi, main komputer, dan main handphone ponsel. (Kurniasih 2013)

Dalam hal ini yang menjadi perhatian utama peneliti ialah anak-anak usia dini di TK Melati Sambiroto yang lebih menyukai bermain dan belajar lewat smartphone, dari latar belakang di atas sehingga rumusan masalah dalam penelitian ini adalah : "Faktor-faktor apa sajakah yang mempengaruhi terjadinya myopia pada anak TK Melati Sambiroto Semarang?". Mengetahui faktor-faktor yang mempengaruhi terjadinya myopia pada anak TK MelatiSambiroto Semarang.

\section{METODE}

Penelitian ini penelitian observasional analitik dengan menggunakan disain cross sectional. Populasi pada penelitian ini adalah semua yang memakai smarthpone anak TK Melati Sambiroto Semarang sebanyak 42.
Sampel dalam penelitian ini adalah seluruh anak TK Melati Sambiroto Semarang. Pengambilan data dilakukan pemeriksaan secara obyektif dengan alat auto refraktometer. Penelitian dilakukan pada bulan Maret-Desember tahun 2015 TK Melati Sambiroto Semarang.

Dalam penelitian ini digunakan dua variabel yaitu variabel independen dan variabel dependen. Dalam penelitian ini dilakukan pengujian dengan mempergunakan uji Chi Square $\left(\mathrm{x}^{2}\right)$ dengan derajat kepercayaan 95\% $(a=0,05)$. Hubungan dikatakan bermakna apabila $p<0,05$. (Sastroasmoro 2011)

\section{HASIL}

\section{Identifikasi pemakaian smartphone}

Usia pemakaian smartphone dimulai dari 2 tahun masa anak-anak mulai belajar meniru dan mengenal dari semua hal. Mulai belajar meniru dari apa yang didengar dan dilihat. Karena alasan kesibukan orang tua yang banyak dituntut untuk menyelesaikan tugas-tugas rumah tangga (ibu rumah tangga) atau tugas kantor (pegawai kantor) dengan alasan supaya anak tidak banyak mengganggu pekerjaan, orang tua tidak harus susah payah dan tidak takut dengan keberadaan anak jauh dari pengawasan, maka anak dikenalkan orang tuanya dengan smartphone, oleh untuk, bermain hingga belajar, orang tua merasa tenang dengan melihat anak diam tidak mengganggu pekerjaan, tanpa berpikir panjang pengaruh atau dampak dari smartphone terhadap kesehatan mata myopia anak.

Mulai mengenalkan anak memakai smartphone hingga anak sekolah durasi atau lamanya memakai semakin bertambah, bahkan anak tidak banyak justru dibelikan. Pada orang tua tidak banyak yang berpikir pengaruh atau dampak dari pemakaian smartphone pada anaknya, sehingga orangtua belum menyadari untuk memeriksakan anak khususnya kesehatan mata.

Pemeriksaan rutin pada mata sebaiknya dimulai pada usia dini. Pada anak usia 2,5-5 tahun, skrining mata perlu dilakukan untuk mendeteksi apakah menderita gangguan tajam penglihatan yang nantinya akan mengganggu aktivitas di sekolahnya (Fachrian dkk, 2009). Masalah penyakit mata pada anak dapat dicegah dengan melakukan deteksi dini untuk mengetahui status ketajaman penglihatan pada anak yang didukung oleh pemeriksaan mata sebagai alat ukur yaitu Snellen card (kartu Snellen). (Fachrian D. Arlia B.R 2009)

\section{Lama penggunaan smartphone}

Kebiasaan dalam bermain atau belajar dengan smartphone bersumber dari keluarga. Smartphone dipakai sehari lebih dari 2 jam mulai anak usia 2 tahun terjadi pada anak TK melati. Bermain satu sampai dua jam bahkan bisa lebih dalam sehari, mulai dari awal kesibukan orang tua hingga selesai, selama anak tidak membuat gaduh orang 


\section{TABEL 1}

Crosstab Lama Penggunaan Smarthphone dengan Kejadian Myopia di TK Sambiroto Semarang Periode Tahun 2015

\begin{tabular}{|c|c|c|c|c|c|}
\hline \multicolumn{3}{|c|}{ Lama Penggunaan } & \multicolumn{2}{|c|}{ Kelainan Refraksi } & \multirow[t]{2}{*}{ Total } \\
\hline & & & Tidak Myopia & Myopia & \\
\hline \multirow{6}{*}{$\begin{array}{l}\text { Lama } \\
\text { Penggunaan }\end{array}$} & Tidak Lama & Count & 17 & 3 & 20 \\
\hline & & Expected Count & 10,0 & 10,0 & 20,0 \\
\hline & & $\%$ within Lama Pemakaian & $85,0 \%$ & $15,0 \%$ & $100,0 \%$ \\
\hline & Lama & Count & 4 & 18 & 22 \\
\hline & & Expected Count & 11,0 & 11,0 & 22,0 \\
\hline & & $\%$ within Lama Pemakaian & $18,2 \%$ & $81,8 \%$ & $100,0 \%$ \\
\hline \multirow[t]{3}{*}{ Total } & & Count & 21 & 21 & 42 \\
\hline & & Expected Count & 21,0 & 21,0 & 42,0 \\
\hline & & $\%$ within Lama Pemakaian & $50,0 \%$ & $50,0 \%$ & $100,0 \%$ \\
\hline
\end{tabular}

TABEL 2

Crosstab Genetik Penggunaan Smarthphone dengan Kejadian Myopia di TK Sambiroto Semarang Periode Tahun 2015

Lama Penggunaan
Kelainan Refraksi

Tidak Myopia

Tidak
myopia

Myopia

Total

Count

Expected Count

$\%$ within Posisi

Count

Expected Count

$\%$ within Posisi

Count

Expected Count

$\%$ within Posisi

18
13,0
$69,2 \%$
3
8,0
$18,8 \%$
21
21,0
$50,0 \%$

13,0

$9,2 \%$

8,0

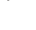

21,0

$50,0 \%$
Total

Myopia

$\begin{array}{cc}8 & 26 \\ 13,0 & 26,0 \\ 30,8 \% & 100,0 \% \\ 13 & 16 \\ 8,0 & 16,0 \\ 81,3 \% & 100,0 \% \\ 21 & 42 \\ 21,0 & 42,0 \\ 50,0 \% & 100,0 \%\end{array}$

tua membiarkan untuk tetap bermain atau belajar dengan smartphone, tidak banyak anak bermain hingga ketiduran. Permainan ditunjang dengan semakin canggihnya smartphone, semakin banyak fasilitas yang membuat betah untuk bermain atau belajar dengan smartphone maka lebih lama waktu yang dihabiskan dalam permainan.

3. Orangtua merupakan faktor utama yang mempengaruhi kondisi seorang anak

Sikap orangtua terhadap kelainan refraksi sangat mempengaruhi perilaku sehat pada anaknya. Sikap positif terhadap kelainan refraksi yang dapat ditunjukan orangtua antara lain sikap setuju terhadap definisi dan gejala kelainan refraksi, koreksi harus segera dilakukan, serta perlunya tindakan pencegahan. Orangtua yang memgalami kelainan refraksi (myopia) Tidak semua sadar akan pengaruh atau dampak baik langsung atau tidak langsung dari diri orangtua terhadap anakanaknya.

Orangtua anak di TK Melati ada beberapa yang mengalami kelainan refraksi myopia ada beberapa yang memakai softlens dan memakaian kacamata. Orangtua yang merasa normal tidak ada keluhan akan tetapi saat 
TABEL 3

Crosstab Posisi Penggunaan Smarthphone dengan Kejadian Myopia di TK Sambiroto Semarang Periode Tahun 2015

\begin{tabular}{|c|c|c|c|c|c|}
\hline \multicolumn{3}{|c|}{ Lama Penggunaan } & \multicolumn{2}{|c|}{ Kelainan Refraksi } & \multirow[t]{2}{*}{ Total } \\
\hline & & & Tidak Myopia & Myopia & \\
\hline \multirow[t]{6}{*}{ Posisi } & Duduk Tegak & Count & 13 & 4 & 17 \\
\hline & & Expected Count & 8,5 & 8,5 & 17,0 \\
\hline & & $\%$ within Posisi & $76,5 \%$ & $23,5 \%$ & $100,0 \%$ \\
\hline & Tidak Tegak & Count & 8 & 17 & 25 \\
\hline & & Expected Count & 12,5 & 12,5 & 25,0 \\
\hline & & $\%$ within Posisi & $32,0 \%$ & $68,0 \%$ & $100,0 \%$ \\
\hline \multirow[t]{3}{*}{ Total } & & Count & 21 & 21 & 42 \\
\hline & & Expected Count & 21,0 & 21,0 & 42,0 \\
\hline & & \% within Posisi & $50,0 \%$ & $50,0 \%$ & $100,0 \%$ \\
\hline
\end{tabular}

dilakukan pemeriksaan hasil menyebutkan ada kelainan refraksi (myopia).

4. Kenyamanan bermain atau belajar dengan smartphone yang berulang-ulang dalam setiap hari menjadikan faktor kebiasaan anak

Anak akan membiasakan bermain atau belajar dengan menggunakan smartphone dengan duduk tegak, duduk tidak tegap, tengkurap dan tiduran adalah posisi yang dilakukan saat melakukan aktifitas. Anak akan bermain atau belajar dengan menggunakan smartphone dalam posisi yang dianggap nyaman. Terdapat banyak anak yang menyukai posisi duduk tidak tegap.

\section{PEMBAHASAN}

\section{Lama Penggunaan Smartphone}

Salah satu klasifikasi yang sering dipakai ialah berdasarkan rekomendasi waktu maksimum dari The American Academi of Pediatrics. Asosiasi ini merekomendasikan waktu maksimum 2 jam/sehari untuk anak dan remaja diatas 2 tahun untuk screen based activity. Banyak riset menggunakan standar ini untuk mengklasifikasikan screen time. (Kairupan, T. 2012).

Berdasarkan Tabel 1 diketahui hasil pengolahan data menggunakan uji Chi Square menggunakan program Statistical Program for Social Sciences (SPSS), lama Penggunaan menunjukkan bahwa anak-anak yang bermain atau belajar dengan smartphone kategori lama yaitu lebih dari 2 jam sebanyak 18,2\% tidak berstatus myopia dan $81,8 \%$ dengan status refraksi myopia. Nilai probabilitas $p=0,000$ menunjukan bahwa ada hubungan yang bermakna antara lama Penggunaan dengan kejadian myopia.

\section{Faktof Genetik}

Dalam penelitian didapatkan faktor krturunan atau genetik berhubungan dengan myopia. Hal ini mengikuti pola dose respone pattern di mana anak yang kedua orang tuanya mengalami myopia memiliki kemungkinan hampir $100 \%$ mengalami myopia dibandingkan hanya salah satu orang tua yang mengalami myopia $(78,9 \%)$ dan keduanya tidak mengalami myopia (63,4\%). (Dirani M 2008)

Berdasarkan Tabel 2 diketahui hasil pengolahan data menggunakan uji Chi Square menggunakan program Statistical Program for Social Sciences (SPSS), faktor genetik dari orang tua berstatus myopi, didapatkan hasil anak tidak berstatus myopia menunjukkan $18,8 \%$, dan orang tua berstatus myopia, anak mengalami myopia menunjukan $81,3 \%$. Nilai probabilitas $(p=0.004)$ menunjukan bahwa ada hubungan antara faktor genetik dengan kejadian myopia.

\section{Posisi Penggunaan}

Dalam penggunaan smartphone yang salah dalam pengujian statistic menurut (Wati.N 2008) tentang hubungan antara posisi duduk tidak tegak $(65,7 \%)$ dengan ketajaman pengelihatan. Dalam penelitian tentang hubungan antara posisi membaca dengan ketajaman penglihatan memiliki nilai $p=0,000 \quad(p<0,05)$ sehingga menunjukan ada hubungan antara kebiasaan posisi saat membaca dengan gangguan penurunan ketajaman penglihatan.

Berdasarkan Tabel 3 diketahui hasil pengolahan data menggunakan uji Chi Square menggunakan program Statistical Program for Social Sciences (SPSS), posisi pemakaian smartphone dengan duduk tidak tegak dan tidak berstatus myopia $(32,0 \%)$ dari duduk tidak tegak 
dengan status refraksi myopia menunjukkan $(68,0 \%)$ anak.

Nilai probabilitas $p=0,012$ menunjukan bahwa ada hubungan antara posisi pemakaian smartphone dengan kejadian myopia. Dalam pengambilan data dilakukan sesaat, satu kali dalam penelitian, data didapat dari wawancara orang tua tidak melihat langsung saat bermain smartphone di rumah, jadi peneliti jangan puas dengan hasil yang didapat, hasil berhubungan bisa karena pengaruh hasil awal sudah mengalami myopia.

\section{SIMPULAN}

Ada hubungan yang bermakna antara lama pemakaian smartphone dengan kejadian myopia pada anak TK Melati diSambiroto Semarang.

Ada hubungan antara faktor genetik dengan kejadian myopia pada anak TK Melati di Sambiroto Semarang.

Ada hubungan antara posisi menggunakan smartphone dengan kejadian myopia pada anak TK Melati diSambirotoSemarang.

Diharapkan bagi orang tua agar lebih memperhatikan kesehatan mata anak dengan cara mengatur waktu anak di depan layar serta jarak saat anak saat bermain atau belajar mengunakan smartphone.

Bagi orang tua yang memiliki riwayat kelainan refraksi myopia harus lebih memperhatikan anak khususnya kesehatan mata, pemeriksaan kesehatan mata sangatlah dianjurkan.

Posisi pemakaian smartphone dalam penelitian ini ada hubungan. Bagi orang tua harus lebih memperhatikan posisi-posisi saat menggunakan smartphone untuk anak karena posisi yang tidak benar atau tidak baik akan berdampak tidak hanya pada mata saja melainkan pada kesehatan anggota tubuh anak yang masih dalam masa pertumbuhan. Anggota tubuh yang mengalami kelainan karena posisi duduk yang salah berdampak pada tulang belakang seperti: skoliosis, lordosis, kifosis.

\section{DAFTAR PUSTAKA}

Agustina, Rika. "Pengaruh game online terhadap perubahan perilaku agresif remaja di Semarang." eJurnal Ilmu Komunikasi.ejurnal.ilkom.fisip.umul.ac.id, 2016:1-2.

Dirani M, Chambelain M. "The gene in myopia (GEM)twin study." Investigative Ophthalmology and Visual Science www.iovs.org/cgi/content/abstract, 2008.

Djua, Nurlaila. "Gambaran faktor-faktor yang mempengaruhi progresivitas penderita myopia di klinin mata di RSUD Gorontalo." Jurnal Keperawatan, 2015: 6.

Fachrian D. Arlia B.R, Apep .J.N. "prevalensi kelainan tajam pengelihatan pada pelajar SD." Indonesia digital journals, 2009: 6.

Ilyas, Sidarta. kelainan refraksi dan koreksi pengelihatan. Jakarta: Balai penerbit FKUI, 2008.

Juniver V Mokalu, Norma N. Mewangkang, Joane P.M Tangkudung. "Dampak teknologi smartphone terhadap perilaku orang tua di desa Touure." e-jurnal"Acta Diurna Volume V. No 1, 2016:1.

Kairupan T. "Hubungan antara aktivitas fisik dan screen Time dengan status gizi pada siswa-siswi SMP Kristen Eben Haezar." 2012.

Kurniasih. Sembuhkan Mata Minus dengan Takokak. . Yogyakarta: Pustaka Baru, 2013.

Makasar, Kelainan Refraksi pada anak usia 3-6 Tahun di kecamatan Tallo Kota. "Anastasia Vanny Launardo, Achmad Afifudin, Noor Syamsu dan Rahasiah Taufik."

Nurkasih, Indah. "Hubungan antara kerja jarak dekat dengan myopia." Jakarta. Maj Kedokt Indonesia. Jurnal volume 60, 2010.

Sastroasmoro, S. Dasar-dasar metodologi penelitian klinis. Jakarta: Edisi ke-4.Sagung Seto;. hlm. 102, 251, 2011.

Surtiretna, N. Mengenal Sistem Indra. Bandung: PT.Kiblat Buku Utama, 2012.

Wati.N. "Skrining Gangguan Tajam Pengelihatan(visusu) Anak Usia 7-10 tahun Sekolah Dasar." ejournal respati.ac.id/sites/default, 2008:3. 